\title{
The Influence of Substitution of a Phosphorus-Containing Polyol with the Bio-polyol on the Properties of Bio-based PUR/PIR Foams
}

\author{
Kamila Gosz ${ }^{1}$ Józef Haponiuk ${ }^{1} \cdot$ Łukasz Piszczyk $^{1,2}$
}

Published online: 14 June 2018

(c) The Author(s) 2018

\begin{abstract}
In this work, effects of incorporating of a phosphorus-containing polyol into rigid polyurethane/polyisocyanurate foams' formulations developed with use of two different bio-based polyols, derived from crude glycerol or liquefied cellulose were examined. The bio-polyol derived from crude glycerol was synthesized via two-step process from crude glycerol and castor oil, whereas the bio-polyol derived from liquefied cellulose was prepared in lignocellulose biomass liquefaction process. Rigid polyurethane/polyisocyanurate foams were prepared by substitution 25, 50, 75 and $100 \mathrm{wt} \%$ of a bio-polyol with the phosphorus-containing polyol. Density, compressive modulus, thermal stability and chemical and cellular structure content of the PUR/PIR foams were studied. Cell morphology was also observed by scanning electron microscopy. Furthermore, thermal stability and flammability were investigated. The results show that the phosphorus-based polyol favors some PUR/ PIR foams properties such as fire retardancy, what was expected, but also compressive strength behavior.
\end{abstract}

\section{Introduction}

One of many challenges that polyurethane industry is facing nowadays its dependency on petrochemical products, having two main raw materials, e.g. polyols and isocyanates of petroleum origin. As it was shown in many published works, renewable materials can often substitute their petrochemical analogs with little to none negative influence on final products'properties. With increasing emphasis being put on waste disposal issues and usage of renewable biomass sources, polyurethane-based materials get more attention and a higher number of possible applications [1,2]. The advantages of these materials include their low cost, easy availability, and renewability, better biodegradability, as

Łukasz Piszczyk

lukpiszc@pg.edu.pl

Kamila Gosz

kamila.gosz@pg.edu.pl

Józef Haponiuk

jozef.haponiuk@pg.edu.pl

1 Department of Polymer Technology, Chemical Faculty, Gdansk University of Technology, G. Narutowicza Str. 11/12, 80-233 Gdansk, Poland

2 Present Address: Department of Polymer Technology, Chemical Faculty, Gdansk University of Technology, G. Narutowicza Str. 11/12, 80-233 Gdansk, Poland well as attention-drawing properties related to the plant oil structure [3-5]. A wide range of plant oils is used, namely sunflower oil [6], rapeseed [7], palm [8, 9], castor [4, 10, 11] and soybean [12-15] oils. The number of publications on the synthesis of polyurethanes with the use of plant-based polyols is constantly growing. Petrović et al. [13, 16, 17] obtained polyurethanes using various polyols based on vegetable oils and, he has shown that the thermal stability of urethane groups is influenced by the orderliness of hydroxyl groups. Polyurethanes obtained using polyols with primary hydroxyl groups are more stable than those with secondary ones. PUR derived from castor oil have also higher thermal stability compared to polyurethane materials based on soy oil. Among the various waste components used to obtain PUR foams, the raw glycerol, a by-product from the production of biodiesel, generated on a scale of about 1 million tons per year in Europe alone $[18,19]$ is especially worth mentioning. Due to its low price, it can be considered as an interesting and economically efficient alternative to petrolbased materials, causing various research groups to investigate its use in bio polyol synthesis [20-22].

From bio-based polyols foamed PUR materials were also obtained, but the study of their properties was often limited and included only basic mechanical tests [23, 24]. Hu et al. [12] studied the feasibility of using crude glycerol to liquefy soybean straw for the production of bio-polyols and polyurethane foams. The obtained bio-polyols showed a hydroxyl 
number of 440-540 $\mathrm{mg} \mathrm{KOH} \mathrm{g}^{-1}$ and the produced foams showed densities of $33-37 \mathrm{~kg} \mathrm{~m}^{-3}$ with compressive strength from 148 to $227 \mathrm{kPa}$.

However, polyurethanes are characterized by high flammability, which is accompanied by the emission of toxic gases and large amounts of smoke emitted during combustion. The extremely important factor determining the development of the polymer materials industry is the success in efforts to eliminate toxic compounds and reduce flammability $[25,26]$. Safety requirements for polymer materials in the scope of reaction to fire and their fire resistance are now increasingly stringent. In order to increase the fire safety and to reduce flammability of polyurethane materials, flame retardants are applied. In concern for the environment and human safety, the use of halogen flame retardants has been abandoned. The challenge for flame retardant systems is to be non-harmful to people and the environment [27, 28]. The most commonly used commercially available flame retardants for polyurethane materials include triphenylphosphate [29], phosphoric trichloride with bisphenol A diphosphate [30], aniline and 9,10-dihydro9-oxa-10-phosphaphenanthrene-10-oxide [31, 32], ammonium polyphosphate [33, 34] and tris(1-chloro-2-propyl)phosphate $[35,36]$. Phosphoric polyols belonging to the group of reactive flame retardants of polyurethane foams are noteworthy in particular. Organophosphorus compounds favorably affect the charring and char formation process rendering them very effective due to the fact that they produce during burning a stable form of poly(meta-phosphoric acid), which forms an insulating layer on the surface of the polymer. This modification, however, does affect the properties of the modified materials. Problems related to effective flame retardation of polymers bring this area to intensive research and searching for innovative solutions.

The presented study evaluates the potential use for the synthesis of rigid polyurethane/plyisocyanurate foams of two bio-polyols, one based on crude glycerol and castor oil and one obtained by use raw glycerol to liquefy cellulose. The bio-polyol in the foams'formulation was then replaced from 0 to $100 \%$ by weight with a commercial phosphoric polyol. The chemical structure (FTIR tests) and cell structure (SEM analysis), mechanical (compression tests, dynamic mechanical analysis) and thermal properties (thermogravimetric analysis), photo-oxidative and thermo-oxidative aging and fire behavior of obtained rigid (PUR/PIR) foams were investigated.

\section{Experimental}

\section{Materials}

The bio-based polyol designated LC (like liquefied cellulose) was synthesized by liquefaction of cellulose with the mixture of purified crude glycerol. Cellulose in the form of cotton fiber with a water content of $5.4 \%$ was obtained from VITA Rzeszow (Poland). Refined crude glycerol was acquired from Bio-Chem Sp. z o.o. (Poland). The water content of the crude glycerol was lower than $0.5 \mathrm{wt} \%$ and its density was $1.26 \mathrm{~g} \mathrm{~cm}^{-3}$. The liquefaction process was catalyzed by $95 \%$ aqueous solution of sulfuric acid (VI) obtained from Avantor Performance Materials Poland SA. Detailed description of synthesis and properties of bio-polyol LC was presented by Kosmela et al. [37].

The bio-based polyol designated CG (like crude glycerol) was synthesized from crude glycerol and castor oil. Crude glycerol was acquired from Bio-Chem Sp. z o.o. (Poland), while castor oil was acquired from Pro-Lab (Poland). 85\% aqueous solution of ortophosphoric acid was used as a catalyst and 50\% aqueous solution of sulfuric (VI) acid was used to neutralize reaction products. Both acids were obtained from POCH S.A. (Poland). Particular stages of synthesis were described by Hejna et al. [35].

Rigid PUR/PIR foams were prepared from previously obtained bio-based polyols, noted as LC and CG and commercially available polyol from Clariant company, Exolit OP 560 (E560) a reactive type flame retardant oligomer phosphonate. The properties of the aforementioned polyols are presented in Table 1.

Polymeric methylene diphenyl diisocyanate (pMDI) was supplied by Borsodchem (Hungary). The average functionality of pMDI was ca. 2.8, while the content of free isocyanate groups was $31.5 \%$.

Tin(II) 2-ethylhexanoate [Sn(Oct $\left.)_{2}\right]$, Dabco® TMR7tertiary amine as well as potassium octoate (K15) were used as catalysts. All of those were supplied by Sigma-Aldrich.

Moreover, Tegostab ${ }^{\circledR}$ B 8465, non hydrolysable surfactant obtained from EVONIK Industries AG was chosen. Distilled water and mixture of liquid hydrocarbons Solkane ${ }^{\circledR} 365 / 227$ supplied by Solvay Chemicals International SA. were both used as blowing agents.

\section{Preparation of Polyurethane/Polyisocyanurate Foam}

Rigid polyurethane/polyisoyanurate foams were obtained from the two-component system, with the $\mathrm{NCO} / \mathrm{OH}$ ratio

Table 1 Properties of polyols used for the production of rigid polyurethane/polyisocyanurate foams

\begin{tabular}{llll}
\hline Polyol & CG & LC & E560 \\
\hline Density $\left(\mathrm{g} \mathrm{cm}^{-3}\right)$ & 1.18 & 2.7 & 1.20 \\
OH number $\left(\mathrm{mg} \mathrm{KOH} \mathrm{g}^{-1}\right)$ & 580 & 750 & 450 \\
Viscosity (mPa s) & 840 & 150 & 500 \\
Water content (\%) & 0.21 & 0.63 & 0.01 \\
\hline
\end{tabular}


of 2:1 using one-step method. Component A was obtained by thorough mixing (rotational speed of $1800 \mathrm{rpm}$, mixing time $60 \mathrm{~s}$ ) of the appropriate amounts of Exolit OP 560 and bio-polyol CG or LC, catalysts, surfactants and blowing agents. Phosphorous containing polyol Exolit OP 560 was incorporated as a substitute- in the foam formulation of 25 , 50, 75 and 100 parts by weight of a bio-polyol CG or LC. Component $\mathrm{B}$ consisted of an isocyanate pMDI. Components $\mathrm{A}$ and $\mathrm{B}$ were mixed together at the selected mass ratio in at polypropylene cup and the mixture was poured into a mold. Thus obtained foams were annealed in an oven at $60{ }^{\circ} \mathrm{C}$ for approx. $24 \mathrm{~h}$, and then stabilized at room temperature for $24 \mathrm{~h}$. Tables 2 and 3 contain the details of foams formulations.

\section{Measurements and Characterization}

FT-IR spectrophotometric analysis was performed in order to determine the chemical structure of the obtained polyurethane/polyisocyanurate foams. The analysis was performed at a resolution of $4 \mathrm{~cm}^{-1}$ using a Nicolet 8700 apparatus (Thermo Electron Corporation) equipped with a snap-Gold State II which allows for making measurements in the reflection configuration mode.

The apparent density of PUR/PIR samples was calculated in accordance with PN-EN ISO 845: 2000, as the ratio of the sample weight to the sample volume.

Sol fraction was determined during swelling test. Samples of foams (around $0.2 \mathrm{~g}$ ) were swollen in xylene for $72 \mathrm{~h}$ (room temperature). Sol fraction was calculated as mass difference of samples before swelling $\left(\mathrm{W}_{1}\right)$ and after extraction $\left(\mathrm{W}_{2}\right)$, according to Eq. (1)

Sol fraction $=\frac{\mathrm{W}_{1}-\mathrm{W}_{2}}{\mathrm{~W}_{1}} \times 100 \%$

The compression strength of rigid foams was estimated in accordance with PN-EN ISO 604:2006. The compression
Table 3 Formulation of LC foams

\begin{tabular}{|c|c|c|c|c|c|}
\hline & \multicolumn{5}{|c|}{ Foam's symbol } \\
\hline & $\mathrm{LC}_{100}$ & $\mathrm{LC}_{25} \mathrm{E} 560_{75}$ & $\mathrm{LC}_{50} \mathrm{E} 560_{50}$ & $\mathrm{LC}_{75} \mathrm{E} 560_{25}$ & E560 100 \\
\hline $\mathrm{LC}$ & 100 & 25 & 50 & 75 & - \\
\hline E560 & - & 75 & 50 & 25 & 100 \\
\hline K15 & 4.1 & 4.1 & 4.1 & 4.1 & 2 \\
\hline TMR7 & 4.1 & 4.1 & 4.1 & 4.1 & 2 \\
\hline $\mathrm{Sn}(\mathrm{Oct})_{2}$ & 0.4 & 0.4 & 0.4 & 0.4 & 0.4 \\
\hline Surfactant & 2.5 & 2.5 & 2.4 & 2.5 & 2.5 \\
\hline Water & 0.7 & 0.7 & 0.7 & 0.7 & 0.7 \\
\hline Solkane & 34.2 & 34.2 & 34.2 & 34.4 & 34.4 \\
\hline pMDI & 334.2 & 253.8 & 283.8 & 307.8 & 228.3 \\
\hline
\end{tabular}

test was performed on a Zwick/Roell tensile tester at a constant speed of $10 \mathrm{~mm} \mathrm{~min}^{-1}$ to $40 \%$ deformation.

The thermogravimetric analysis (TGA) was performed on a Netzsch TG 209 apparatus using 5-mg samples within the temperature range $100-600{ }^{\circ} \mathrm{C}$ under a nitrogen atmosphere, at a heating rate of $15^{\circ} \mathrm{C} / \mathrm{min}$.

The cell morphology of polyurethane/polyisocyanurate samples was investigated with a Philips-FEI XL 30 environmental scanning electron microscope (ESEM) using an acceleration of $25 \mathrm{kV}$. The samples were cut at room temperature, while the observations were performed in wet mode.

The dynamic mechanical analysis was performed using DMA Q800 TA Instruments apparatus. Samples were analyzed in compression mode with a frequency of $1 \mathrm{~Hz}$. Measurements were performed for the temperature range from 25 to $270{ }^{\circ} \mathrm{C}$ with heating rate $4{ }^{\circ} \mathrm{C} \mathrm{min}{ }^{-1}$. The glass transition temperature $\left(\mathrm{T}_{\mathrm{g}}\right)$ of PUR/PIR foams was measured by $\mathrm{E}^{\prime}$ onset.

\section{Photo-Oxidative Aging of Rigid PUR/PIR Foams}

Foams were subjected to photo-oxidative aging due to ultraviolet radiation (UV-A) according to EN 927-6:2007 standard. Samples were irradiated with UV-A 340 lamps,
Table 2 Formulation of CG foams

\begin{tabular}{llllll}
\hline \multicolumn{5}{l}{ Foam's symbol } \\
\cline { 2 - 6 } & $\mathrm{CG}_{100}$ & $\mathrm{CG}_{25} \mathrm{E} 560_{75}$ & $\mathrm{CG}_{50} \mathrm{E} 560_{50}$ & $\mathrm{CG}_{75}{\mathrm{E} 560_{25}}$ & ${\mathrm{E} 560_{100}}$ \\
\hline $\mathrm{CG}$ & 100 & 25 & 50 & 75 & - \\
E560 & - & 75 & 50 & 25 & 100 \\
K15 & 2 & 2 & 2 & 2 & 2 \\
TMR7 & 2 & 2 & 2 & 2 & 2 \\
Sn(Oct) ${ }_{2}$ & 0.4 & 0.4 & 0.4 & 0.4 & 0.5 \\
Surfactant & 2.5 & 2.5 & 2.5 & 2.5 & 2.5 \\
Water & 0.7 & - & 0.7 & 0.7 & 0.7 \\
Solkane & 34.2 & 34.2 & 34.2 & 34.4 & 34.4 \\
pMDI & 253.8 & 241.0 & 253.8 & 266.3 & 228.3 \\
\hline
\end{tabular}


$\lambda=360 \mathrm{~nm}$, which accounts for the energy of $\sim 330 \mathrm{~kJ} \mathrm{~mol}^{-1}$. Such energy is enough to cause dissociation of bonds present in polyurethane/polyisocyanurate backbone and generate free radicals initiating decomposition processes. Aging was performed in an air atmosphere at a constant temperature of $23{ }^{\circ} \mathrm{C}$ and relative humidity of $60 \%$.

\section{Thermo-0xidative Aging of Rigid PUR/PIR Foams}

Foams were subjected to thermo-oxidative aging in accordance with ASTM D3574-03 standard. Cylindrical samples were kept at $140{ }^{\circ} \mathrm{C}$ for $22 \mathrm{~h}$. After that, samples were cooled down before further analyses.

\section{Results and Discussion}

Figure 1 shows the values of apparent density and compressive strength of prepared rigid polyurethane/polyisocyanurate foams are presented. The apparent density of (PUR/PIR) foams usually affects greatly their mechanical strength, due to its increase compressive strength also raises $[6,38]$.

Compressive strength and apparent density ranged between 105 and $375 \mathrm{kPa}$ and $39-43 \mathrm{~kg} \mathrm{~m}^{-3}$ respectively. A direct correlation between bio-polyol content and both compressive strength and foam density was observed. Similar interrelationships associated with application of bio-polyols in (PUR/PIR) foams were observed before [39].

Polyurethane/polyisocyanurate foams obtained with crude glycerol derived polyol show better mechanical properties which suggests that not only apparent density but also chemical structure and foam morphology have an effect on compressive strength. Structure anisotropy visible on SEM images indicates differences in mechanical properties, which has been noticed in other paper [40].

The FTIR spectra of the analyzed materials are presented in Fig. 2. Symmetrical and the asymmetric stretching vibrations of $\mathrm{N}-\mathrm{H}$ groups can be observed in the range between 3325 and $3299 \mathrm{~cm}^{-1}$. Signals at $1519-1509 \mathrm{~cm}^{-1}$ correspond to bending vibrations of these groups. Signals at $2928-2900 \mathrm{~cm}^{-1}$ represent asymmetric $\mathrm{C}-\mathrm{H}$ stretching vibrations in the $\mathrm{CH}_{2}$ groups present in the aliphatic chains and $\mathrm{CH}_{3}$ of the terminal groups. The low intensity of the peaks at $2357-280 \mathrm{~cm}^{-1}$ results from the presence of unreacted $-\mathrm{N}=\mathrm{C}=\mathrm{O}$ groups, which indicates that the excess of isocyanate was used relatively to the polyol content [41, 42]. This is related to the aforementioned peaks present in the urethane groups in the range of $1406-1414 \mathrm{~cm}^{-1}$, which have been assigned to the isocyanurate rings derived from the trimerization of isocyanates [43]. The presence of carbonyl $\mathrm{C}=\mathrm{O}$ bonds in urethane groups was observed at $1718-1707 \mathrm{~cm}^{-1}$. Signals at $1596-1591 \mathrm{~cm}^{-1}$ represent aromatic groups present in ultra-fine polyurethane/polyisocyanurate foams [44]. The tensile vibrations in the range of
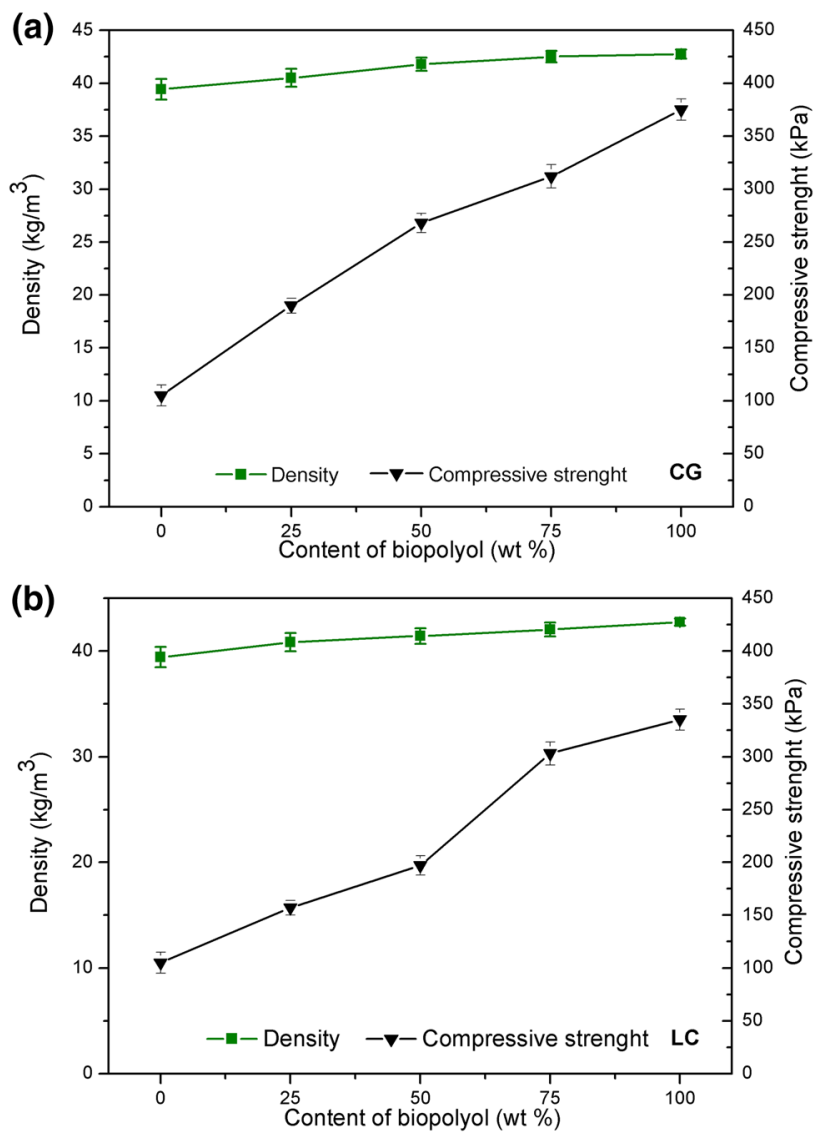

Fig. 1 The effect of bio-polyol content on compressive strength and density of PUR/PIR foams for a CG and b LC

$1221-1211 \mathrm{~cm}^{-1}$ corresponded to $\mathrm{C}-\mathrm{N}$ groups. The signals at $1062-1072 \mathrm{~cm}^{-1}$ were assigned to the $\mathrm{C}-\mathrm{O}$ groups present in the flexible segments in polyurethane chains [45]. The $967-962 \mathrm{~cm}^{-1}$ signals correspond to the asymmetric vibrations of the $\mathrm{P}-\mathrm{O}-\mathrm{C}$ group that have been observed in materials containing more than 50\% of the E560 polyol [46]. Detailed analysis of shifts attributed to different ratios of polyols used in rigid polyurethane/polyisocyanurate materials can be found in Tables 4 and 5.

The hydrogen bonding index $(\mathrm{R})$ and the content of rigid polyurethane/polyisocyanurate segments may be used to calculate phase separation degree (DSP) from the FTIR results [45]. The indicator $(R)$ was analyzed based on the intensity of the multiplet bands derived from the carbonyl groups present in the urethane and urea formations. For this purpose, a baseline for carbonyl vibration $\left(1770-1630 \mathrm{~cm}^{-1}\right)$ was determined. Using the Gaussian curve fitting method applying Origin 6.0 software, the intensity of these bands was estimated.

The hydrogen bond ratio was calculated using the following equation:

$R=\frac{A_{1}+A_{2}}{A_{3}+A_{4}}$ 

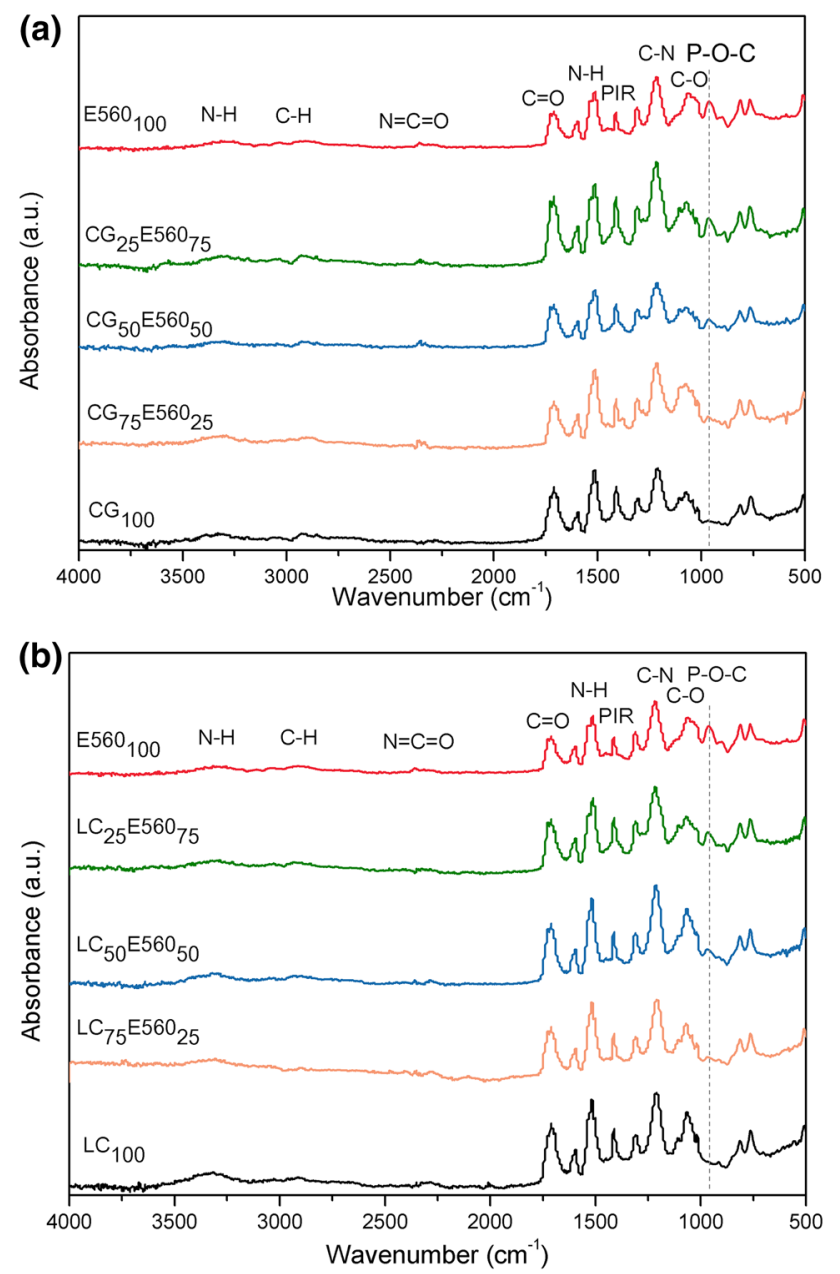

Fig. 2 FTIR spectra of prepared PUR/PIR foams a CG and b LC

having $A_{1}, A_{2}$ as a range of bands corresponding to hydrogen bonded carbonyl bonding in urea groups $\left(1640-1686 \mathrm{~cm}^{-1}\right)$ and urethane groups (1705-1724 $\left.\mathrm{cm}^{-1}\right) ; \mathrm{A}_{3}, \mathrm{~A}_{4}$ as a range of bands corresponding to carbonyl not bound by hydrogen in urea groups (1690-1702 $\left.\mathrm{cm}^{-1}\right)$ and urethane groups $\left(1732-1760 \mathrm{~cm}^{-1}\right)$.

Based on the hydrogen bonding index $(\mathrm{R})$ value the phase separation degree (DSP) parameter has been calculated using the following equation:

$D S P=\frac{R}{R+1}$

The data from Table 6 indicate that phase separation depends on the content of bio-polyol in the test material. The highest hydrogen bonding ratio was obtained for $\mathrm{CG}_{75} \mathrm{E}_{560_{25}}$ $(\mathrm{R}=1.68)$. The introduction of $\mathrm{CG}$ biopolymer resulted in the formation of more hydrogen bonds compared to the foam using E560 ${ }_{100}$. These changes may be due to the plasticizing effect of the phosphorus polyol. The higher crosslinking degree is associated with an increase in the hardness of the hard segments, and this has resulted in a rise in compressive strength in the case of materials with high bio-polyol content [7].

Parameters describing the cell structure of the analyzed materials are presented in Table 7. All parameters were determined from the microscope images (SEM) shown in Fig. 3. The foams' formulations were modified by varying the amount of Solkane ${ }^{\circledR}$ blowing agent to ensure uniform apparent density. Increasing bio-polyol CG or LC content has reduced the amount of physical blowing agent required to provide the same level of volume expansion during foaming, which is a great advantage in economic and technological terms.

In order to determine the shape parameters like aspect ratio (AR) and roundness ( $\mathrm{R}$ ) of the pores, the computer program fitted the ellipses to the foam cells. The parameters were determined based on the corresponding mathematical equations:

$A R=\frac{L_{l}}{L_{s}}$

$R=4 \times \frac{A}{\pi \times L_{l}^{2}}$
Table 4 Analysis of signals in FTIR spectroscopy of CG materials

\begin{tabular}{|c|c|c|c|c|c|}
\hline $\begin{array}{l}\mathrm{CG}_{100} \\
\text { Wavenum- } \\
\text { ber }\left(\mathrm{cm}^{-1}\right)\end{array}$ & $\mathrm{CG}_{75} \mathrm{E} 560_{25}$ & $\mathrm{CG}_{50} \mathrm{E}_{560}{ }_{50}$ & $\mathrm{CG}_{25} \mathrm{E}_{560}{ }_{75}$ & E560 100 & Bond (vibration) \\
\hline 3325 & 3303 & 3299 & 3314 & 3300 & $\mathrm{~N}-\mathrm{H}$ (stretching) \\
\hline 2928 & 2900 & 2920 & 2920 & 2908 & $\mathrm{C}-\mathrm{H}$ (asymmetric stretching) \\
\hline 2280 & 2363 & 2357 & 2357 & 2357 & $\mathrm{~N}=\mathrm{C}=\mathrm{O}$ (stretching) \\
\hline 1711 & 1707 & 1709 & 1708 & 1716 & $\mathrm{C}=\mathrm{O}$ (stretching) \\
\hline 1593 & 1592 & 1593 & 1592 & 1596 & Ar-H (deformation) \\
\hline 1512 & 1509 & 1512 & 1509 & 1510 & $\mathrm{~N}-\mathrm{H}$ (bending) \\
\hline 1410 & 1406 & 1410 & 1409 & 1414 & PIR (deformation) \\
\hline 1211 & 1218 & 1213 & 1215 & 1221 & $\mathrm{C}-\mathrm{N}$ (stretching) \\
\hline 1068 & 1069 & 1072 & 1068 & 1062 & $\mathrm{C}-\mathrm{O}$ (stretching) \\
\hline- & - & 964 & 965 & 962 & $\mathrm{P}-\mathrm{O}-\mathrm{C}$ (asymmetric stretching) \\
\hline
\end{tabular}


Table 5 Analysis of signals in FTIR spectroscopy of LC materials

\begin{tabular}{|c|c|c|c|c|c|}
\hline $\begin{array}{l}\mathrm{LC}_{100} \\
\text { Wavenum- } \\
\text { ber }\left(\mathrm{cm}^{-1}\right)\end{array}$ & $\mathrm{LC}_{75} \mathrm{E}_{560}{ }_{25}$ & $\mathrm{LC}_{50} \mathrm{E} 560_{50}$ & $\mathrm{LC}_{25} \mathrm{E} 560_{75}$ & $\mathrm{E} 560_{100}$ & Bond (vibration) \\
\hline 3314 & 3306 & 3314 & 3300 & 3300 & $\mathrm{~N}-\mathrm{H}$ (stretching) \\
\hline 2908 & 2900 & 2920 & 2928 & 2908 & $\mathrm{C}-\mathrm{H}$ (asymmetric stretching) \\
\hline 2280 & 2268 & 2363 & 2361 & 2357 & $\mathrm{~N}=\mathrm{C}=\mathrm{O}$ (stretching) \\
\hline 1712 & 1707 & 1711 & 1718 & 1716 & $\mathrm{C}=\mathrm{O}$ (stretching) \\
\hline 1595 & 1591 & 1595 & 1595 & 1596 & Ar-H (deformation) \\
\hline 1516 & 1516 & 1519 & 1514 & 1510 & $\mathrm{~N}-\mathrm{H}$ (bending) \\
\hline 1409 & 1407 & 1412 & 1412 & 1414 & PIR (deformation) \\
\hline 1211 & 1211 & 1214 & 1217 & 1221 & $\mathrm{C}-\mathrm{N}$ (stretching) \\
\hline 1065 & 1068 & 1066 & 1069 & 1062 & $\mathrm{C}-\mathrm{O}$ (stretching) \\
\hline- & - & 967 & 966 & 962 & $\mathrm{P}-\mathrm{O}-\mathrm{C}$ (asymmetric stretching) \\
\hline
\end{tabular}

Table 6 Hydrogen bonding index $(\mathrm{R})$ and phase separation degree (DPS) of tested PUR/ PIR samples

\begin{tabular}{lll}
\hline Sample & $\mathrm{R}$ & $\mathrm{DSP}(\%)$ \\
\hline $\mathrm{CG}_{100}$ & 1.57 & 61 \\
$\mathrm{CG}_{75} \mathrm{E} 60_{25}$ & 1.68 & 63 \\
$\mathrm{CG}_{50} \mathrm{E}_{56} 0_{50}$ & 1.49 & 60 \\
$\mathrm{CG}_{25} \mathrm{E} 560_{75}$ & 1.48 & 60 \\
$\mathrm{E}_{60} 0_{100}$ & 1.53 & 60 \\
$\mathrm{LC}_{100}$ & 1.54 & 61 \\
$\mathrm{LC}_{75} \mathrm{E} 560_{25}$ & 1.53 & 60 \\
$\mathrm{LC}_{50} \mathrm{E} 560_{50}$ & 1.50 & 60 \\
$\mathrm{LC}_{25} \mathrm{E} 560_{75}$ & 1.52 & 60 \\
\hline
\end{tabular}

where $L_{l}$ and $L_{s}$ are the respective lengths of the major and minor axes of an ellipse, and $A$ stands for the square area of the ellipse.

For perfectly round pores, the values of $A R$ and $R$ are equal to 1 . It has been observed that the introduction of biopolyols into foam systems does not significantly affect the shape of cells with an $A R$ of 1.6 and $R$ equal to 0.7 . This demonstrates the uniform evaporation of the blowing agent during the foaming process. The introduction of $\mathrm{CG}$ and
LC to foams resulted in a reduction in the pore diameter, as can be seen in Fig. 3. This is due to the fact that biopolyol affects the cell nucleation process in the initial phase of foams'formation. Also, the amount of blowing agent used increases the cell size [47].

Table 7 also shows the content of the sol fraction of PUR/PIR rigid foams. Increasing content of CG and LC resulted in a reduction of sol fraction, which is related to the increased density of crosslinking of material [48].

The data presented in Table 7 indicate an increase in the glass transition temperature ( $\mathrm{Tg}$ ) with the increasing content of bio-polyol in the polyols mixture. This is confirmed by the results obtained during the swell equilibration and by tensile strength tests. Similar results from the introduction of bio-polyol to rigid PUR/PIR foams were also reported in another study [49]. The authors linked $\mathrm{T}_{\mathrm{g}}$ growth with the reduced elasticity of the bio-polyol chains as compared to the commercial polyol due to an increased number of higher order hydroxyl groups which increased the crosslinking density of the material.

The results of the thermogravimetric analysis of the tested PUR/PIR foams are presented in Table 8 . The temperature
Table 7 Parameters describing the cellular structure of the obtained materials

\begin{tabular}{|c|c|c|c|c|c|}
\hline \multirow[t]{2}{*}{ Foam symbol } & \multicolumn{4}{|l|}{ Properties } & \multirow[t]{2}{*}{$\mathrm{T}_{\mathrm{g}} \mathrm{E}^{\prime}\left({ }^{\circ} \mathrm{C}\right)$} \\
\hline & $\begin{array}{l}\text { Average cell } \\
\text { diameter }(\mu \mathrm{m})\end{array}$ & Cell aspect ratio & Cell roundness & $\begin{array}{l}\text { Sol fraction } \\
\text { (wt } \%)\end{array}$ & \\
\hline $\mathrm{CG}_{100}$ & 145 & 1.56 & 0.71 & 3.84 & 225 \\
\hline $\mathrm{CG}_{75} \mathrm{E} 560_{25}$ & 156 & 1.47 & 0.73 & 5.03 & 191 \\
\hline $\mathrm{CG}_{50} \mathrm{E}_{560_{50}}$ & 183 & 1.48 & 0.73 & 6.06 & 185 \\
\hline $\mathrm{CG}_{25} \mathrm{E} 560_{75}$ & 208 & 1.52 & 0.71 & 7.00 & 172 \\
\hline $\mathrm{E} 560_{100}$ & 242 & 1.64 & 0.70 & 4.80 & 203 \\
\hline $\mathrm{LC}_{100}$ & 181 & 1.55 & 0.69 & 1.65 & 207 \\
\hline $\mathrm{LC}_{75} \mathrm{E} 50_{25}$ & 194 & 1.58 & 0.70 & 2.29 & 184 \\
\hline $\mathrm{LC}_{50} \mathrm{E} 60_{50}$ & 199 & 1.67 & 0.67 & 4.91 & 182 \\
\hline $\mathrm{LC}_{25} \mathrm{E} 560_{75}$ & 214 & 1.63 & 0.71 & 7.11 & 150 \\
\hline
\end{tabular}



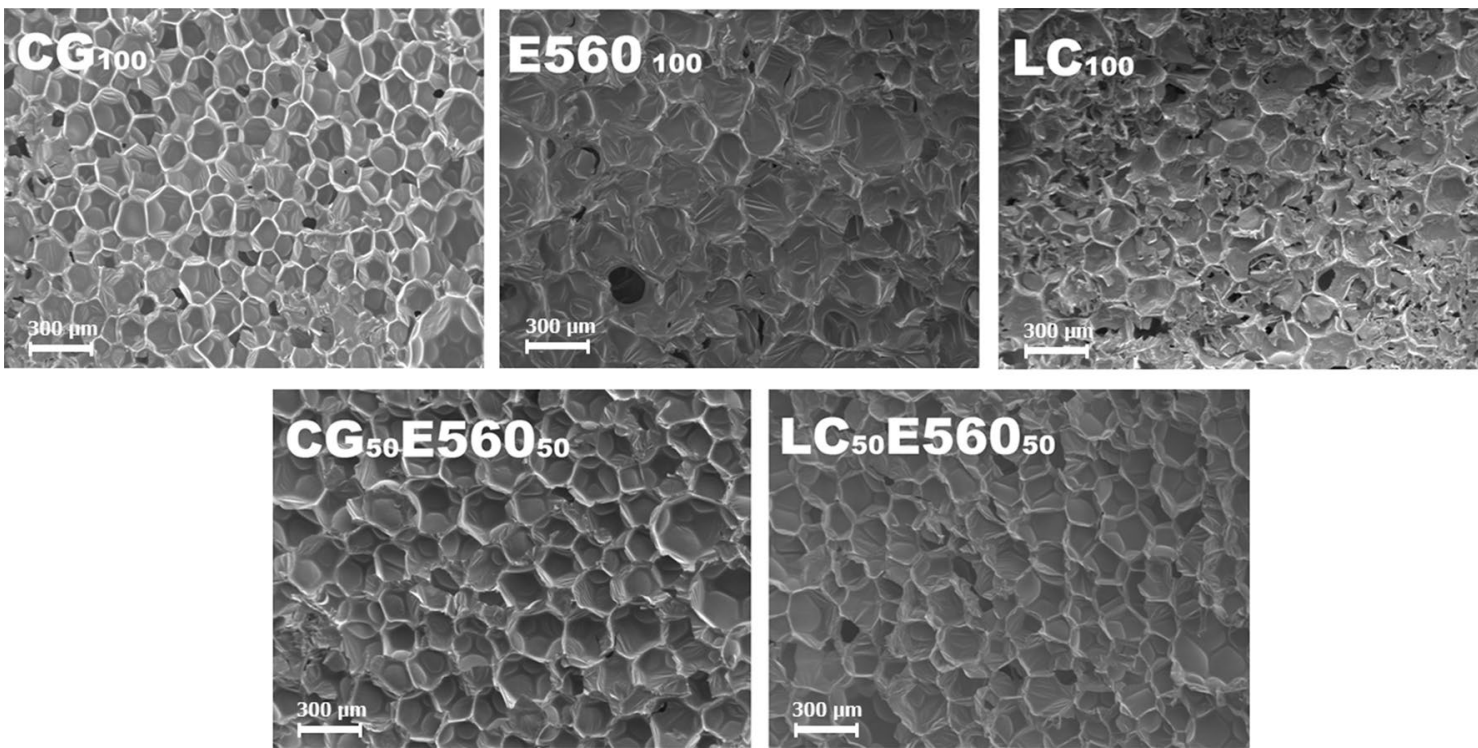

Fig. 3 SEM microscope images of rigid PUR/PIR foams

values for the beginning of the thermal degradation and individual values of the sample weight loss and the temperature positions of the peaks present on the differential thermogravimetry (DTG) are presented. In addition, Fig. 4 shows the DTG curves of the investigated foams.

Thermal degradation of polyurethanes is a very complex process due to the diversity of its structure. Introduction of bio-polyol to rigid PUR/PIR foams has led to an increase in the temperature of early stage of thermal degradation. Figure 4 and Table 8 . show that the phosphorus contained in E560 polyol accelerates degradation by shifting $\mathrm{T}_{\max 1}$ and $\mathrm{T}_{\max 2}$ to lower temperatures while simultaneously stabilizing the second degradation [46]. The first one corresponded to the cleavage of the urethane-urea linkages and the second degradation step to the degradation of the polyol Then, about $300{ }^{\circ} \mathrm{C}$, the degradation of rigid polyurethane segments begins, which consists in the breakdown of biuret, allophanate and urethane bonds leading to the formation of low molecular amines, intermediates and carbon dioxide $[8$, 50-52].

Replacing the phosphorus polyol through CG and LC resulted in a shift of the peaks on the DTG curves to higher temperatures, which confirms the increased thermal stability of the foams. This may also suggest a decrease in the amount of volatile compounds and an improvement in the thermal resistance of rigid segments in the obtained materials.

Also very important from the application point of view is the flammability of rigid PUR/PIR foams used as thermal insulation materials because it is directly related to the safety of health and human life. In order to determine the flammability of the foams obtained, they were tested using the UL 94 flammability test.
Table 8 Characteristics of thermal degradation in rigid polyurethane/polyisocyanurate foams

\begin{tabular}{|c|c|c|c|c|c|c|c|}
\hline \multirow[t]{3}{*}{ Sample } & \multirow{3}{*}{$\begin{array}{l}\text { Onset of deg- } \\
\text { radation }\left({ }^{\circ} \mathrm{C}\right)\end{array}$} & \multicolumn{2}{|c|}{ Mass loss (\%) } & \multirow[t]{3}{*}{$\mathrm{T}_{\max 1}\left({ }^{\circ} \mathrm{C}\right)$} & \multirow[t]{3}{*}{$\mathrm{T}_{\max 2}\left({ }^{\circ} \mathrm{C}\right)$} & \multirow[t]{3}{*}{$\mathrm{T}_{\max 3}\left({ }^{\circ} \mathrm{C}\right)$} & \multirow[t]{3}{*}{$\mathrm{T}_{\max 4}\left({ }^{\circ} \mathrm{C}\right)$} \\
\hline & & 5 & 10 & & & & \\
\hline & & \multicolumn{2}{|c|}{ Temperature $\left({ }^{\circ} \mathrm{C}\right)$} & & & & \\
\hline $\mathrm{CG}_{100}$ & 280.4 & 191.8 & 242.2 & 181.3 & 309.4 & 411.5 & 470.4 \\
\hline $\mathrm{CG}_{75} \mathrm{E} 50_{25}$ & 272.0 & 207.8 & 247.0 & 233.4 & 327.1 & - & - \\
\hline $\mathrm{CG}_{50} \mathrm{E}_{560_{50}}$ & 239.0 & 216.4 & 236.0 & 233.6 & 322.7 & - & - \\
\hline $\mathrm{CG}_{25} \mathrm{E} 560_{75}$ & 231.9 & 210.6 & 227.8 & 227.4 & 320.5 & 415.5 & - \\
\hline E560 100 & 246.2 & 248.1 & 262.2 & 272.3 & 318.5 & 385.7 & - \\
\hline $\mathrm{LC}_{100}$ & 230.5 & 185.2 & 260.1 & 172.4 & 248.8 & 329.9 & 397.9 \\
\hline $\mathrm{LC}_{75} \mathrm{E} 560_{25}$ & 227.7 & 219.6 & 249.8 & 276.1 & 328.5 & 372.2 & - \\
\hline $\mathrm{LC}_{50} \mathrm{E}_{560}$ & 227.2 & 220.6 & 235.2 & 234.4 & 326.3 & 417.5 & - \\
\hline $\mathrm{LC}_{25} \mathrm{E} 560_{75}$ & 222.0 & 217.7 & 230.8 & 230.5 & 320.4 & 415.2 & \\
\hline
\end{tabular}



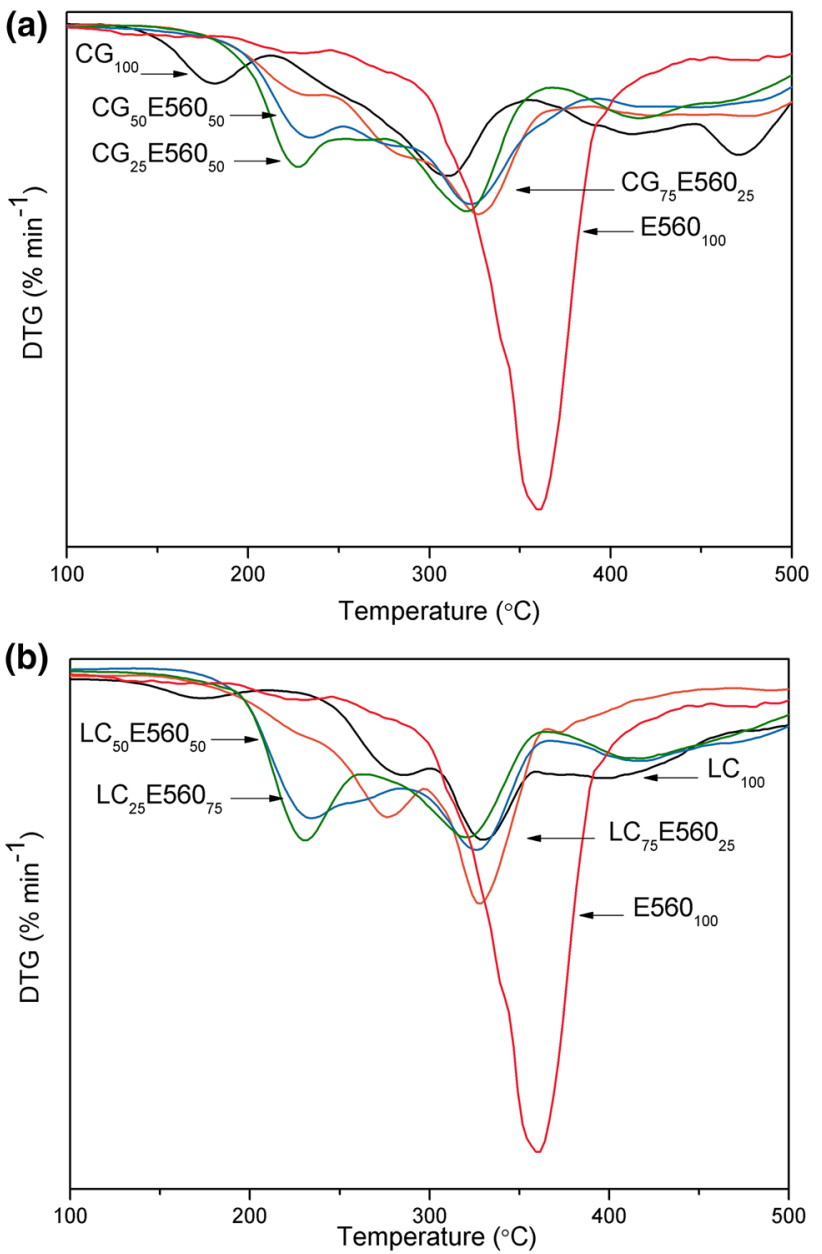

Fig. 4 DTG curves of the prepared PUR/PIR foams a CG and b LC

As shown in Table 9, the CG100 and LC100 do not meet the flammability class according to UL $94 \mathrm{HB}$ and $\mathrm{V}-0$ due to the high flame range. Containing $25 \%$ of the weight of the phosphoric polyol resulted in a change in the combustion of the material compared to the sample, which should be considered as an advantage of this modification.

The accelerated aging process was also used to better understand the effect of the rigid polyurethane/polyisocyanurate foam degradation process on mechanical properties and apparent density as shown in Figs. 5 and 6. Evident differences in compressive strength and apparent density were observed for materials subjected to thermo-oxidative aging. The $\mathrm{CG}_{50} \mathrm{E} 560_{50}$ foam exhibits a $10 \%$ reduction in mechanical strength in the case of photo-aging and a 50\% reduction in thermo-oxidative aging. Similar results were obtained for $\mathrm{LC}_{50} \mathrm{E}_{560}$ foam with a compression strength of $15 \%$ for photodegradation and $27 \%$ for thermo-oxidative aging. The decrease in mechanical properties has also been described by Leuteritz et al. [53].
Table 9 Parameters describing the flammability of the prepared rigid PUR/PIR foams

\begin{tabular}{|c|c|c|c|}
\hline Sample & UL $94 \mathrm{HB}$ & UL $94 \mathrm{~V}$ & $\begin{array}{l}\text { Flame } \\
\text { range } \\
(\mathrm{mm})\end{array}$ \\
\hline $\mathrm{CG}_{100}$ & - & - & 112 \\
\hline $\mathrm{CG}_{75} \mathrm{E} 50_{25}$ & HB-A & $\mathrm{V}-0$ & $30 \pm 2$ \\
\hline $\mathrm{CG}_{50} \mathrm{E} 50_{50}$ & HB-A & $\mathrm{V}-0$ & $20 \pm 1$ \\
\hline $\mathrm{CG}_{25} \mathrm{E} 560_{75}$ & HB-A & $\mathrm{V}-0$ & $12 \pm 2$ \\
\hline $\mathrm{E} 560_{100}$ & HB-A & V-0 & $11 \pm 3$ \\
\hline $\mathrm{LC}_{100}$ & - & - & 124 \\
\hline $\mathrm{LC}_{75} \mathrm{E} 560_{25}$ & HB-A & V-0 & $21 \pm 3$ \\
\hline $\mathrm{LC}_{50} \mathrm{E} 560_{50}$ & HB-A & $\mathrm{V}-0$ & $16 \pm 2$ \\
\hline $\mathrm{LC}_{25} \mathrm{E} 560_{75}$ & HB-A & $\mathrm{V}-0$ & $12 \pm 2$ \\
\hline
\end{tabular}

Figure 7. shows FTIR spectra of rigid PUR/PIR foams subjected to thermal- and photo-oxidation processes to determine the effect of these processes on the chemical structure of the materials analyzed. The results are similar to those reported by other researchers [54]. Photo-oxidative aging produces a new band near $1770 \mathrm{~cm}^{-1}$ which indicates the formation of carbonyl groups by oxidation. The band between 2900 and $2928 \mathrm{~cm}^{-1}$ comes from $\mathrm{CH}_{2}$ and is connected to chemical reactions involving these groups, under the influence of UV radiation and elevated temperatures [55]. There is also a change in the intensity and shape of the band at $3299-3325 \mathrm{~cm}^{-1}$ (N-H stretching) which indicates the breakdown of urethane groups by UV radiation. This phenomenon has also been confirmed by Romanova et al. [56]. Significant changes in the FTIR spectrum are more evident for photo-oxidative aged materials. Differences in the intensity of spectra show changes in the area of carbonyl groups (1800-1600 $\mathrm{cm}^{-1}$ ) due to UV-induced oxidation. The range in this area is wider, indicating the emergence of new structures containing $\mathrm{C}=\mathrm{O}$ bond.

\section{Conclusions}

Rigid polyurethane/polyisocyanurate foams were prepared by substitution 25, 50, 75 and $100 \mathrm{wt} \%$ of a bio-polyol with the phosphorus-containing polyol. The bio-polyols which were used for production foams were synthesized via two-step process from crude glycerol and castor oil and lignocellulose biomass liquefaction process. The hydroxyl numbers of polyols were respectively: crude glycerol (CG) $\mathrm{L}_{\mathrm{OH}}=560 \mathrm{mg} \mathrm{KOH} / \mathrm{g}$, lignocellulose biomass (LC) $\mathrm{L}_{\mathrm{OH}}=750 \mathrm{mg} \mathrm{KOH} \mathrm{g}^{-1}$ and phosphorus-containing polyol (E560) $\mathrm{L}_{\mathrm{OH}}=450 \mathrm{mg} \mathrm{KOH} \mathrm{g}^{-1}$. Formulations of foams were adjusted to provide a similar apparent density of analyzed materials. The compressive strength of foams decreased with increasing amounts phosphorus-containing polyol reaching 

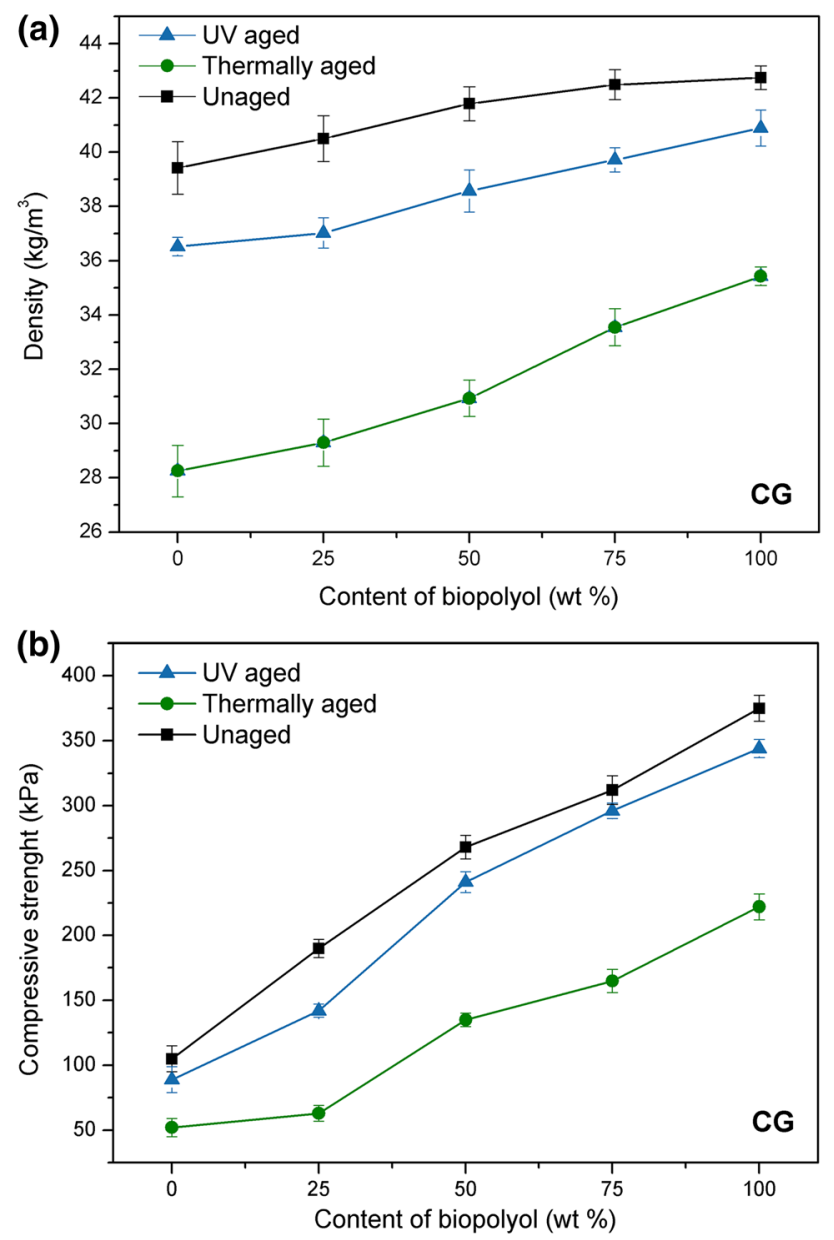

Fig. 5 Effect of bio-polyol content $\mathbf{a}$ on density and $\mathbf{b}$ compressive strength of PUR/PIR and CG foams

a value of $105 \mathrm{kPa}$ for foams containing only phosphorus polyol. The SEM photos of the surface of rigid (PUR/ PIR) foams showed increased of cell size with the addition of E560 polyol and changes in cell aspect ratio and cell roundness. Replacement of the bio-polyol by phosphoruscontaining polyol resulted in higher of thermal stability of foams. $25 \%$ of weight addition of phosphoric polyol renders these materials capable of fulfilling the flammability classes HB-1 and V-0. The impact of thermo-oxidative and photo-oxidative aging on the structure and properties of rigid polyurethane/polyisocyanurate foams was also investigated. The apparent density and mechanical properties of phosphorus-containing polyol based PUR/PIR decreased
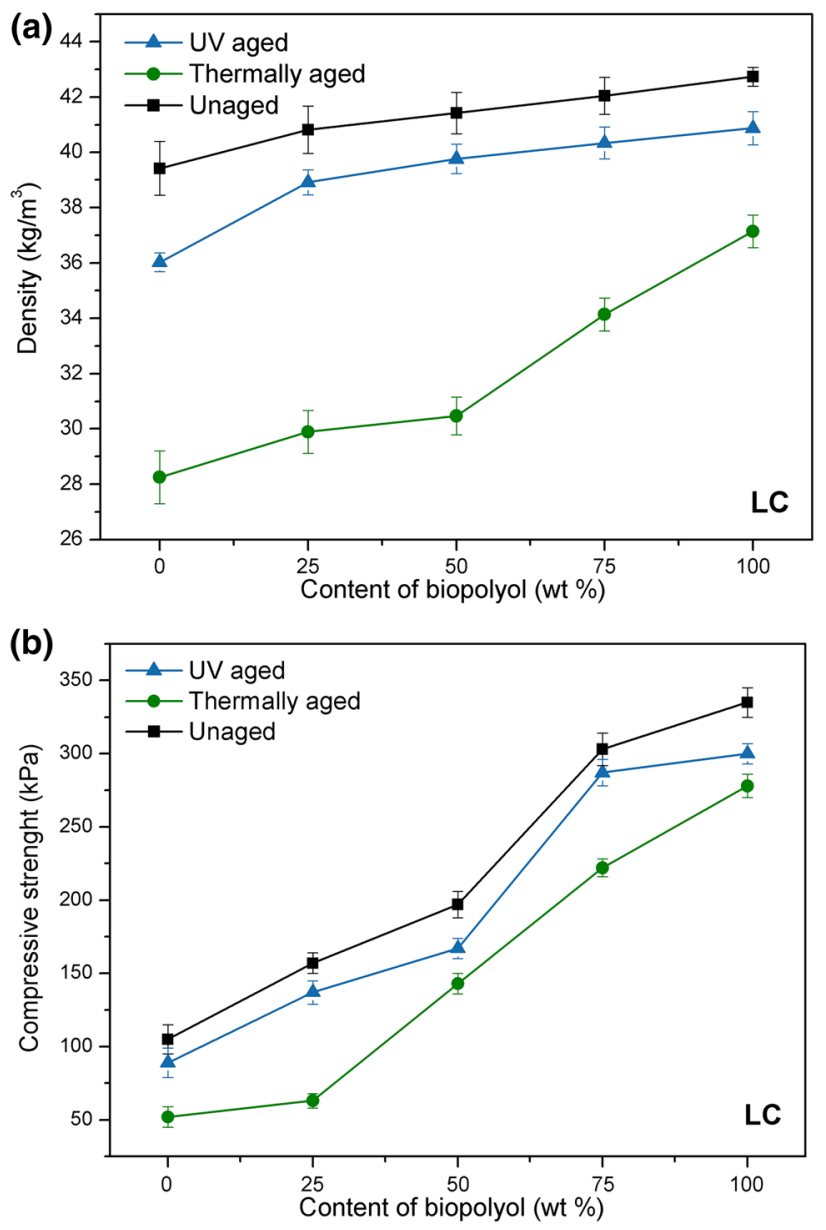

Fig. 6 Effect of bio-polyol content $\mathbf{a}$ on density and $\mathbf{b}$ compressive strength of PUR/PIR and LC foams

obviously with aging process time. Bigger changes in the apparent density and compressive strength were observed for thermo-oxidative aging.

Summarizing, this work confirms that two types of biopolyols can be successfully applied in the production of polyurethane/polyisocyanurate foams. Foams produced with the use of obtained bio-polyols are characterized by acceptable mechanical and their properties. The result shows also that substitution $25 \mathrm{wt} \%$ bio-polyols by phosphorus-containing polyol caused the foams fulfilling the flammability classes.

Open Access This article is distributed under the terms of the Creative Commons Attribution 4.0 International License (http://creativeco mmons.org/licenses/by/4.0/), which permits unrestricted use, distribution, and reproduction in any medium, provided you give appropriate credit to the original author(s) and the source, provide a link to the Creative Commons license, and indicate if changes were made. 

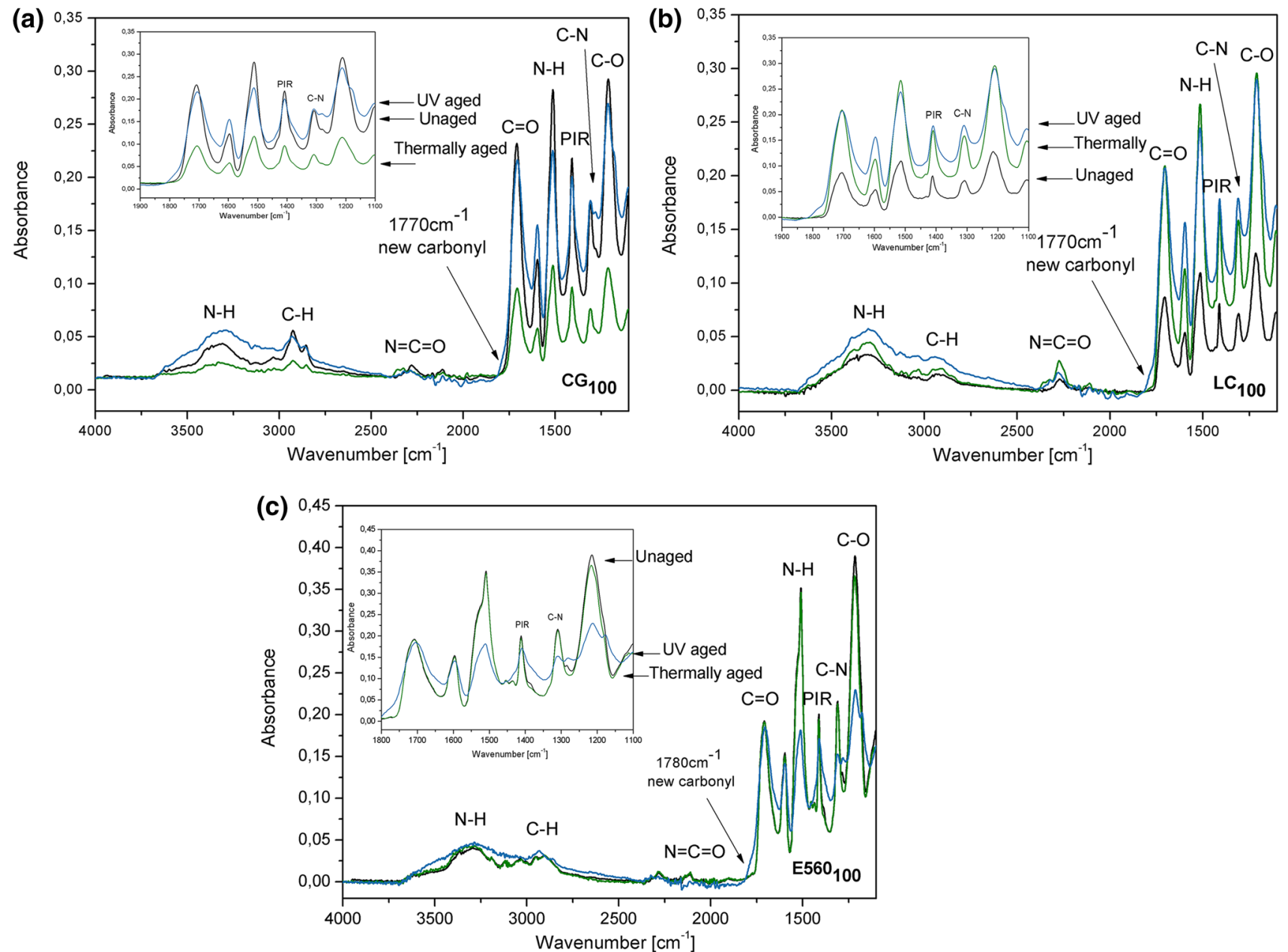

Fig. 7 FTIR spectra of prepared PUR/PIR foams a $\mathrm{CG}_{100}, \mathbf{b} \mathrm{LC}_{100}$ and $\mathbf{c} \mathrm{E} 560_{100}$

\section{References}

1. Deka H, Karak N (2009) Bio-based hyperbranched polyurethanes for surface coating applications. Prog Org Coat 66:192-198. https ://doi.org/10.1016/j.porgcoat.2009.07.005

2. Hatti-Kaul R, Törnvall U, Gustafsson L, Börjesson P (2007) Industrial biotechnology for the production of bio-based chemicals - a cradle-to-grave perspective. Trends Biotechnol 25:119124. https://doi.org/10.1016/j.tibtech.2007.01.001

3. Sharma V, Kundu PP (2008) Condensation polymers from natural oils. Prog Polym Sci 33:1199-1215. https://doi.org/10.1016/j. progpolymsci.2008.07.004

4. Hablot E, Zheng D, Bouquey M, Avérous L (2008) Polyurethanes based on castor oil: kinetics, chemical, mechanical and thermal properties. Macromol Mater Eng 293:922-929. https:// doi.org/10.1002/mame.200800185

5. Lu Y, Larock RC (2008) Soybean-oil-based waterborne polyurethane dispersions: effects of polyol functionality and hard segment content on properties. Biomacromolecules 9:3332-3340. https:// doi.org/10.1021/bm801030g

6. Prociak A (2008) Heat-insulating properties of rigid polyurethane foams synthesized with use of vegetable oils-based polyols. Polimery 53:195-200
7. Zieleniewska M, Leszczyński MK, Kurańska M et al (2015) Preparation and characterisation of rigid polyurethane foams using a rapeseed oil-based polyol. Ind Crops Prod 74:887-897. https:// doi.org/10.1016/j.indcrop.2015.05.081

8. Tanaka R, Hirose S, Hatakeyama H (2008) Preparation and characterization of polyurethane foams using a palm oil-based polyol. Bioresour Technol 99:3810-3816. https://doi.org/10.1016/j.biort ech.2007.07.007

9. Nik Pauzi NNP, Majid A, Dzulkifli R, Yahya MH MY (2014) Development of rigid bio-based polyurethane foam reinforced with nanoclay. Compos B 67:521-526. https://doi.org/10.1016/j. compositesb.2014.08.004

10. Zhang M, Pan H, Zhang L et al (2014) Study of the mechanical, thermal properties and flame retardancy of rigid polyurethane foams prepared from modified castor-oil-based polyols. Ind Crops Prod 59:135-143. https://doi.org/10.1016/j.indcrop.2014.05.016

11. Ionescu M, Radojčić D, Wan X et al (2016) Highly functional polyols from castor oil for rigid polyurethanes. Eur Polym $\mathbf{J}$ 84:736-749. https://doi.org/10.1016/j.eurpolymj.2016.06.006

12. Hu S, Wan C, Li Y (2012) Production and characterization of biopolyols and polyurethane foams from crude glycerol based liquefaction of soybean straw. Bioresour Technol 103:227-233. https://doi.org/10.1016/j.biortech.2011.09.125 
13. Guo A, Ivan J, Petrovic Z (2000) Rigid polyurethane foams based on soybean oil. J Appl Polym Sci 77:467-473

14. Narine SS, Kong X, Bouzidi L, Sporns P (2007) Physical properties of polyurethanes produced from polyols from seed oils: I. Elastomers. JAOCS. J Am Oil Chem Soc 84:55-63. https:// doi.org/10.1007/s11746-006-1006-4

15. Tan S, Abraham T, Ference D, Macosko CW (2011) Rigid polyurethane foams from a soybean oil-based Polyol. Polymer 52:2840-2846. https://doi.org/10.1016/j.polymer.2011.04.040

16. Husic $S(2005)$ Thermal and mechanical properties of glass reinforced soy-based polyurethane composites. Compos Sci Technol 65:19-25. https://doi.org/10.1016/j.compscitech.2004.05.020

17. Petrovic $Z$ (2008) Polyurethanes from vegetable oils. Polym Rev 48:109-155. https://doi.org/10.1080/15583720701834224

18. Puri M, Abraham RE, Barrow CJ (2012) Biofuel production: prospects, challenges and feedstock in Australia. Renew Sustain Energy Rev 16:6022-6031. https://doi.org/10.1016/j. rser.2012.06.025

19. Ragauskas AJ (2006) The path forward for biofuels and biomaterials. Science 311:484-489. https://doi.org/10.1126/science.11147 36

20. Din NSMNM., Idris Z, Kian YS, Hassan HA (2013) Preparation of polyglycerol from palm-biodiesel crude glycerin. J Oil Palm Res 25:289-297

21. Cheng D, Wang L, Shahbazi A et al (2014) Characterization of the physical and chemical properties of the distillate fractions of crude bio-oil produced by the glycerol-assisted liquefaction of swine manure. Fuel 130:251-256. https://doi.org/10.1016/j. fuel.2014.04.022

22. Hu S, Li Y (2014) Polyols and polyurethane foams from base-catalyzed liquefaction of lignocellulosic biomass by crude glycerol: effects of crude glycerol impurities. Ind Crops Prod 57:188-194. https://doi.org/10.1016/j.indcrop.2014.03.032

23. Ionescu M, Petrović ZS (2010) High functionality polyether polyols based on polyglycerol. J Cell Plast 46:223-237. https://doi. org/10.1177/0021955X09355887

24. Luo X, Hu S, Zhang X, Li Y (2013) Thermochemical conversion of crude glycerol to biopolyols for the production of polyurethane foams. Bioresour Technol 139:323-329. https://doi.org/10.1016/j. biortech.2013.04.011

25. Bourbigot S, Duquesne S (2007) Fire retardant polymers: recent developments and opportunities. J Mater Chem 17:2283. https:// doi.org/10.1039/b702511d

26. Kiliaris P, Papaspyrides CD (2014) Polymers on fire. Polym Green Flame Retard. https://doi.org/10.1016/B978-0-444-53808 $-6.00001-9$

27. Hale RC, Kim SL, Harvey E et al (2008) Antarctic research bases: local sources of polybrominated diphenyl ether (PBDE) flame retardants. Environ Sci Technol 42:1452-1457. https://doi. org/10.1021/es702547a

28. Hale R et al (2001) Persistent pollutants in land-applied sludges. Nature 412:140-141. https://doi.org/10.1016/j.echo.2007.08.009

29. Thirumal M, Singha NK, Khastgir D et al (2010) Halogen-free flame-retardant rigid polyurethane foams: Effect of alumina trihydrate and triphenylphosphate on the properties of polyurethane foams. J Appl Polym Sci 21:NA. https://doi.org/10.1002/ app. 31626

30. Chigwada G, Wilkie CA (2003) Synergy between conventional phosphorus fire retardants and organically-modified clays can lead to fire retardancy of styrenics. Polym Degrad Stab 81:551-557. https://doi.org/10.1016/S0141-3910(03)00156-3

31. Zhang M, Luo Z, Zhang J et al (2015) Effects of a novel phosphorus-nitrogen flame retardant on rosin-based rigid polyurethane foams. Polym Degrad Stab 120:427-434. https://doi. org/10.1016/j.polymdegradstab.2015.08.001
32. Gaan S, Liang S, Mispreuve $\mathrm{H}$ et al (2015) Flame retardant flexible polyurethane foams from novel DOPO-phosphonamidate additives. Polym Degrad Stab 113:180-188. https://doi.org/10.1016/j. polymdegradstab.2015.01.007

33. Guo C, Zhou L, Lv J (2013) Effects of expandable graphite and modified ammonium polyphosphate on the flame-retardant and mechanical properties of wood flour-polypropylene composites. Polym Polym Compos 21:449-456. https://doi.org/10.1002/app25 933

34. Zheng X, Wang G, Xu W (2014) Roles of organically-modified montmorillonite and phosphorous flame retardant during the combustion of rigid polyurethane foam. Polym Degrad Stab 101:3239. https://doi.org/10.1016/j.polymdegradstab.2014.01.015

35. Hejna A, Kosmela P, Kirpluks M et al (2017) Structure, mechanical, thermal and fire behavior assessments of environmentally friendly crude glycerol-based rigid polyisocyanurate foams. J Polym Environ. https://doi.org/10.1007/s10924-017-1086-2

36. Xi W, Qian L, Chen Y et al (2015) Addition flame-retardant behaviors of expandable graphite and [bis(2-hydroxyethyl) amino]-methyl-phosphonic acid dimethyl ester in rigid polyurethane foams. Polym Degrad Stab 122:36-43. https://doi. org/10.1016/j.polymdegradstab.2015.10.013

37. Kosmela P, Hejna A, Formela K et al (2016) Biopolyols obtained via crude glycerol-based liquefaction of cellulose: their structural, rheological and thermal characterization. Cellulose 23:2929-2942. https://doi.org/10.1007/s10570-016-1034-7

38. Mosiewicki MA, Dell'Arciprete GA, Aranguren MI, Marcovich NE (2009) Polyurethane foams obtained from castor oil-based polyol and filled with wood flour. J Compos Mater 43:30573072. https://doi.org/10.1177/0021998309345342

39. Piszczyk $€$, Strankowski M, Danowska M et al (2014) Rigid polyurethane foams from a polyglycerol-based polyol. Eur Polym J 57:143-150. https://doi.org/10.1016/j.eurpolymj.2014.05.012

40. Modesti M, Lorenzetti A (2003) Improvement on fire behaviour of water blown PIR-PUR foams: use of an halogen-free flame retardant. Eur Polym J 39:263-268. https://doi.org/10.1016/ S0014-3057(02)00198-2

41. Chen X, Huo L, Jiao C, Li S (2013) TG-FTIR characterization of volatile compounds from flame retardant polyurethane foams materials. J Anal Appl Pyrolysis 100:186-191. https:// doi.org/10.1016/j.jaap.2012.12.017

42. Molyneux S, Stec AA, Hull TR (2014) The effect of gas phase flame retardants on fire effluent toxicity. Polym Degrad Stab 106:36-46. https://doi.org/10.1016/j.polymdegradstab .2013 .09 .013

43. Jiao L, Xiao H, Wang Q, Sun J (2013) Thermal degradation characteristics of rigid polyurethane foam and the volatile products analysis with TG-FTIR-MS. Polym Degrad Stab 98:26872696. https://doi.org/10.1016/j.polymdegradstab.2013.09.032

44. Coleman MM, Skrovanek DJ, Hu J, Painter PC (1988) Hydrogen bonding in polymer blends. 1. FTIR studies of urethane-ether blends. Macromolecules 21:59-65. https://doi.org/10.1021/ ma00179a014

45. Pretsch T, Jakob I, Müller W (2009) Hydrolytic degradation and functional stability of a segmented shape memory poly(ester urethane). Polym Degrad Stab 94:61-73. https://doi. org/10.1016/j.polymdegradstab.2008.10.012

46. Gómez-Fernández S, Ugarte L, Peña-Rodriguez C et al (2016) The effect of phosphorus containing polyol and layered double hydroxides on the properties of a castor oil based flexible polyurethane foam. Polym Degrad Stab 132:41-51. https://doi. org/10.1016/j.polymdegradstab.2016.03.036

47. Harpal Singh AKJ (2007) Effect of chemical and physical blowing agents on the density, cell morphology and flammability of rigid polyurethane foams. In: Polyurethane 2007 Technical Conference, Orlando, FL, pp 1-15 
48. Yang L-T, Zhao C-S, Dai C-L et al (2012) Thermal and mechanical properties of polyurethane rigid foam based on epoxidized soybean oil. J Polym Environ 20:230-236. https://doi. org/10.1007/s10924-011-0381-6

49. Sormana JL, Meredith JC (2004) High-throughput discovery of structure-mechanical property relationships for segmented poly(urethane-urea)s. Macromolecules 37:2186-2195. https:// doi.org/10.1021/ma035385v

50. Somani KP, Kansara SS, Patel NK, Rakshit AK (2003) Castor oil based polyurethane adhesives for wood-to-wood bonding. Int J Adhes Adhes 23:269-275. https://doi.org/10.1016/S0143 -7496(03)00044-7

51. Cervantes-Uc JM, Espinosa JIM, Cauich-Rodríguez JV et al (2009) TGA/FTIR studies of segmented aliphatic polyurethanes and their nanocomposites prepared with commercial montmorillonites. Polym Degrad Stab 94:1666-1677. https:// doi.org/10.1016/j.polymdegradstab.2009.06.022

52. Garrido MA, Font R (2015) Pyrolysis and combustion study of flexible polyurethane foam. J Anal Appl Pyrolysis 113:202-215. https://doi.org/10.1016/j.jaap.2014.12.017
53. Leuteritz A, Döring K-D, Lampke T, Kuehnert I (2016) Accelerated ageing of plastic jacket pipes for district heating. Polym Test 51:142-147. https://doi.org/10.1016/j.polymertesting.2016.03.012

54. Yarahmadi N, Vega A, Jakubowicz I (2017) Accelerated ageing and degradation characteristics of rigid polyurethane foam. Polym Degrad Stab 138:192-200. https://doi.org/10.1016/j.polymdegra dstab.2017.03.012

55. Paberza A, Stiebra L, Cabulis U (2015) Photodegradation of polyurethane foam obtained from renewable resource-pulp production byproducts. J Renew Mater 3:19-27. https://doi.org/10.7569/ JRM.2014.634138

56. Romanova V, Begishev V, Karmanov V et al (2002) Fourier transform Raman and Fourier transform infrared spectra of cross-linked polyurethaneurea films synthesized from solutions. J Raman Spectrosc 33:769-777. https://doi.org/10.1002/jrs.914 